\title{
HANS ARP: SCULPTOR AND POET
}

\author{
Christopher Middleton \\ (University of London, King's College)
}

The question of intercognition between the arts often remains a vague one, applied to relations between different media, because poems by painters or paintings by poets (like Coethe's drawings) are seldom more than curiosities and are sometimes worse. The case of Hans Arp is different. He has excelled as a sculptor and as a poet as well, in an age moreover of profound intellectual disturbance which has compelled artists and poets alike to question the fundamentals of their media. Arp is not of course the only artist of his generation who has been curious about words. Grosz, Kandinsky, Klee and Schwitters also wrote German verse, but none of them with Arp's consistency and skill. New poems by Arp have been appearing in Germany, with intermissions, for forty years; and, though die-hards like Hermann Hesse have had to review his work with embarrassment, he has effected something like a one-man revolution in Cerman verse. Possibly this revolution could only have been effected by a poet disciplined in non-verbal techniques. At all events, one or two suggestions about his work as a poet may raise the question of intercognition on a more practical level than is customary.

In his preface to the selection Wortträume und schwarze Sterne (Wiesbaden, Limes Verlag, 1953), Arp records his first experiments in 1903 as a boy of sixteen. He was then interested in unusual word-combinations and in "unusable verbs formed from nouns". Born in Strasbourg, a bilingual city, Arp's upbringing there may have enabled him at this early age to treat German (like his contemporary Ivan Goll, who also came from Strasbourg) with that detachment which was later to be fostered by his living in Meudon, near Paris. German no doubt is also more flexible than French; and, though Arp has written stories in 
French, the word-telescopings which he drew for his poems from dreams, newspaper advertisments and medieval legends, could be more adequately formed in German than in French. The poems of 1903 must have been the prototypes of the Dadaist, Arpads' with which he astonished the patrons of the Café Voltaire in Zürich in 1917.

Hugo Ball was associated with Arp at this time. In his journal he recorded that Arp now advocated the discipline of abstract art, and that he was more interested in the primal functions of imagination than the images which enshrine them. Ball was soon to abandon the Dadaist adventure; but Arp remained as ever the obdurate artist, seeking, as Ball put it, to "purify imagination" of the excesses active in Expressionism. One is therefore hardly surprised to find Otto Flake saying in his novel Nein und Ja (in which several Zürich Dadaists appear), that one painting by Arp depicted the most metaphysical potatoes that he had ever seen. Flake's attitude, however, shifts somewhat, and before long he strictures Arp for "playing with causality" in his Dadaist poems. These were such poems as the freely associative' Configurations', now reprinted in Worte mit und ohne Anker (Wiesbaden, Limes Verlag, 1957). They contain such statements as: "upholstered lions hurtle past on soft fingers", or "movement pumps a cellar full of larks". They are oneiric statements which meant more to the Transition writers of the 1930's than they do to English writers today. Since Otto Flake's interest in 1917 was political and quasi-philosophical, he did not notice that Arp was then investigating, as a painter and a poet, the orders of chance, as opposed to those of causality. Collaboration with chance would be an apter description of his aims at this time. He accepted the unpredictable in nature, the normalization of perception by habit being a condition which art does not tolerate. It is not that Arp was cultivating abstraction to the exclusion of nature; rather he sought to uncover a lost reality by excluding from art all the "illusionist" substitutes for nature. "I love nature," he said later, "but not substitutes for it". And again: "I find that a painting or sculpture which have no object for model are just as concrete and sensual as a leaf or a stone." Now his so-called ageometric sculptures (which become less ageometric after 1930) show 
concretely his objective as a sculptor: Carola Giedion-Welcker has called it "the imaged invention of new optic worlds" which reveal, by contrast, startling new relationships between imaginative forms and those corporeal forms which are presented to normal perception. Arp's verse shows a kindred vision. He has explored language as a datum of imagination, as opposed to language as a system of mediating referential signs, much as he has explored the materials of sculpture in their own and likewise non-referential terms.

Arp does not dehumanize poetry by nonsensifying sentiment. For him, art ceases to be as soon as it ceases to desire freedom from the self-evident. His early attempts to reduce the conventional referential properties of words to a minimum then enabled him later to create, with a tact rare among the woollier hypnologists of Transition, speech-patterns which are as autonomous, and, in their contexts, as concrete and sensual as the shapes which he conjures from other materials as a sculptor. His treatment, in so many poems, of words as non-referential media, may puzzle semasiologists. His punstruck word-telescopings may not even be invariably of interest. But two factors must here command the attention of semasiologists and working poets alike: firstly, his using common words in uncommon ways, constructively, by manipulation of contextual perspective; and secondly, the freshness of his approach to language as a sculptor schooled in media which are as such non-referential. Reading Arp, one may be reminded of Morgenstern, a pioneer in such abstruse spheres of meaning; the image-inventions and macabre humour of the early Expressionist Alfred Lichtenstein may also como to mind. But these poets worked exclusively in words, and their innovations, like those of Gottfried Benn, Arp's contemporary, are of quite a different kind. More recently Paul Celan, a much younger poet, but also brought up in an alien fringe of German-speaking areas, and also living in France, has passed via Surrealism close by Arp's position. But special to Arp, among the poets of his generation, is the initial dislocation of the common elements of speech, and then, after 1925, the refinement of the dislocated elements into adamant poetic statements which impinge upon ordinary discourse, then suddenly illuminate the 
world of ordinary discourse, though their organization is as alien to it as their imagery is alien to that of any ordinary optical world. This is the function of Arp's poetry as a poetry of the grotesque, conforming not to the Attic or classical tradition, which seeks a perfection in harmony, but to its opposite, the Asian tradition, which seeks a perfection in the absurd, and which has evolved in Europe by continuous reciprocation with the Attic tradition.

Arp has called his poems "Verästelungen am Rande des Wahrnehmbaren": "interlacings on the edge of the perceptible". The long poem "Träume vom Tod und vom Leben" ("Dreams of Death and Life") seems to mark one limit of his explorations before 1930; and this poem contains many of the stylistic peculiarities which appear separately in other poems. There is the plain laconic presentation of the absurd, the often gloriously nonsensical. There are the fugue-like sequences of images, which show perhaps the sculptor's delight in being relieved of space and to be working in terms of time. There is the elementary syntax: of the 100 lines of the poem, 83 are simple closed periods without dependent clauses. There is the unpredictable, alternately rushing and loitering rhythm, which seems to conform to no metric scheme at all and is yet wholly authoritative. Finally there are, even in this profoundly serious poem, the shafts of hilarity which are shared by Arp's sculptures: the steely fooling that is the terror of the wise.

Alas, this poem is too long to reproduce in full, too closely constructed to be reproduced in extract, and, in any case, hardly translatable. The earlier poem, "The Barren Lea" (1924-27): which follows, has not the grotesque orphic remoteness of "Dreams of Death and Life", but shows two other aspects of Arp's grotesque art as a poet: caricature and satire. The more recent "Baobab" (1957) might at first seem to relapse into the self-evident; but this is not so. Arp has here reached the point at which he can confront the self-evident without being contaminated. It is therefore not a tale in which the moral substitutes for telling, nor a tale in which the telling betrays illusion. 
POEMS by HANS ARP (1)

\section{BLACK EGGS}

The rivers buck like goats in their tent Silver-rimmed it is by silver billows.

Whips crack and out of the hills emerge the ill-combed shadows of the shepherds.

Black eggs and fool's bells drop from the trees.

Storms rant and drums mount the ass's ears.

Wings skim flowers.

Sources stir in the wild boars' eyes.

("Schwarze Eier", from "Der Vogel Selbdritt", 1911-1915,

Wortträume und schwarze Sterne, 1953).

\section{POEMS bY HANS ARP (2)}

\section{THE BARREN LEA}

Sire So-and-So

pulverizes his parakeet,

till $\mathrm{Pa}$ divorces $\mathrm{Ma}$,

till $\mathrm{Pa}$ divorces $\mathrm{Ma}$,

I said,

and the guys are spunk and free.

Ripe monocles fall from the clouds of flesh.

The grey fountains hobble away on crutches.

Something gets a foothold in the claws.

and from the hats to the shoes

the selfmade udders run dry.

On meadows of quicksilver,

tassels tufts hairs bones feathers dance

round an electrical heart.

The manikins slowly grow more and more taciturn,

frigider and frigider.

The palaeostones and the callow stones

saunter between the background and the foreground

dutifully to and fro.

Something cracks in the bust of air.

The pyramids' breaking voices fade away. 
From the buttonholes of the clouds

the galvanized fungi descend.

Suddenly Sire So-and-So jumps

with a cutting "qui vive"

into the bottomless pit.

But since in fact the bottomless pit is not bottomless,

we see Sire So-and-So

return again resigned to his yawning-chair.

$\mathrm{Pa}, \mathrm{Ma}$ and parakeet mutter

and fall asleep.

("Die unerspriessliche Au", from "Der gestiefelte Stern",

1924-27, Wortträume und schwarze Sterne, 1953).

\section{POEMS by HANS ARP (3)}

\section{BAOBAB}

And she gave birth to a strong healthy boy

who was named Baobab.

The boy grew and grew,

and did not stop growing

and grew as high as the blue of the sky itself.

Baobab's compatriots liked to look into the eyes

of whomsoever they might be talking to.

But this was no longer possible in the case

of a person as tall as Baobab was.

So they lifted a lot of earth

and dug a chasmic hole,

into which Baobab willingly inserted himself,

for he too found it unbearable

not to be able to look into the eyes

of whomsoever he might be talking to.

The earth they lifted

they threw over the edge of their small star

into the emptiness.

After Baobab had spent

a hundred years in this hole,

he began to disappear. 
Every day he grew smaller and smaller, till at length he disappeared altogether.

Now the inhabitants of the small star

were left with nothling but a chasmic hole and a narrow strip of land around the hole, and they looked alternately

into the chasmic hole on their small star and over the edge of their small star into the emptiness.

(From Auf einem Bein, Wiesbaden, Limes Verlag, 1955). 